\title{
A three-dimensional adamantane-like nanoscopic cage built from four iodide-bridged triangular $\mathrm{Mo}_{3} \mathrm{~S}_{7}$ cluster units $\dagger$
}

\author{
Larry R. Falvello, ${ }^{a}$ Rosa Llusar, ${ }^{* b}$ Sonia Triguero ${ }^{b}$ and Cristian Vicent ${ }^{* c}$ \\ Received (in Cambridge, UK) 24th December 2008, Accepted 30th March 2009 \\ First published as an Advance Article on the web 5th May 2009 \\ DOI: $10.1039 / \mathbf{b 8 2 3 2 2 3 g}$
}

Chemical oxidation of a $\mathrm{Mo}_{3} \mathrm{~S}_{7}$ cluster featuring catecholate ligands, namely $\left[\mathrm{Mo}_{3} \mathrm{~S}_{7}\left(\mathrm{Cl}_{4} \text { cat }\right)_{3}\right]^{2-}\left(\mathrm{Cl}_{4}\right.$ cat $=$ tetrachlorocatecholate), allows the isolation of a unique nanoscopic molecular cage made of four iodide-bridged $\mathrm{Mo}_{3} \mathrm{~S}_{7}$ clusters as the kinetically favoured product.

Metal-directed self-assembly is a versatile synthetic approach to produce discrete three dimensional polyhedral or cage compounds. Metal centers bring a variety of coordination sites and bond angles to a supramolecular framework, and in combination with different bridging ligands provide great versatility for chemical and structural modification of the inner cavity. ${ }^{1}$ Recently, the use of multi-nuclear systems with labile positions (for example dimeric $\mathrm{M}_{2}$, where $\mathrm{M}=\mathrm{Mo}, \mathrm{Rh}$ ) to build 3D supramolecular cages has also been explored, and new perspectives have been obtained on the facility for fine tuning the net charge, the magnetic properties and the electronic communication between the metal units. ${ }^{2}$

In this context, the family of triangular $\left[\mathrm{Mo}_{3}\left(\mu_{3}-\mathrm{S}\right)\right.$ $\left.\left(\mu-S_{2}\right)_{3} X_{6}\right]^{2-}(X=$ halide $)$ clusters are promising candidates as building blocks for multi-nuclear aggregates. This is due to the presence of two labile binding sites in a cis configuration (an X-Mo-X angle of $c a .90^{\circ}$, see Scheme 1a), which can be easily occupied by a wide spectrum of ligands. In addition, ligand substitution in the $\left[\mathrm{Mo}_{3} \mathrm{~S}_{7} \mathrm{X}_{6}\right]^{2-}$ dianion can be carried out selectively, affecting all six halide ligands or only the three halides cis to the $\mu_{3}-\mathrm{S}$ sulfur atom, ${ }^{3}$ demonstrating the geometry-guiding versatility of the metal centers (see Scheme $1 \mathrm{~b}$ and c). Therefore, the $\mathrm{Mo}_{3} \mathrm{~S}_{7}$ cluster can be regarded as a tritopic building block to construct convex corners in tetrahedral symmetry-like supramolecular capsules or cages that enclose an isolated nanospace. ${ }^{4}$ To date, all molecular architectures based on $\mathrm{Mo}_{3} \mathrm{~S}_{7}$ cluster entities possess 1 or $2 \mathrm{D}$ character (open structures), including the well known polymeric $\left\{\mathrm{M}_{3} \mathrm{~S}_{7} \mathrm{X}_{2} \mathrm{X}_{4 / 2}\right\}_{n}$ solid phases $(\mathrm{M}=\mathrm{Mo}, \mathrm{W})$,

\footnotetext{
${ }^{a}$ Departamento de Química Inorgánica and I.C.M.A, Universidad de Zaragoza-C.S.I.C, Spain. Fax: + 34-976 76118

${ }^{b}$ Departament de Quimica Física i Analitica, Universitat Jaume I, Av. Sos Baynat s/n, E-12071, Castello, Spain.

E-mail: Rosa.Llusar@qfa.uji.es

Serveis Centrals d'Instrumentació Cientifica, Universitat Jaume I, Av. Sos Baynat s/n, E-12071, Castelló, Spain.

E-mail: barrera@sg.uji.es

$\dagger$ Electronic Supplementary Information (ESI) available: Synthetic and X-ray crystallographic details, elemental analysis, IR, solid state UV-Vis absorption spectra, powder X-ray diffractograms and electrospray ionization-MS data for $\left(\mathrm{PPh}_{4}\right)_{2}[\mathbf{1}],\left(\mathrm{PPh}_{4}\right)_{3}[2]$ and $\left(\mathrm{PPh}_{4}\right)_{2}[3]$. CCDC 713962-713964. For ESI and crystallographic data in CIF or other electronic format see DOI: $10.1039 / \mathrm{b} 823223 \mathrm{~g} /$
}

where each $\mathrm{Mo}_{3} \mathrm{~S}_{7}$ unit is covalently linked to its neighbors through four halide bridges forming zigzag chains. ${ }^{5}$

Herein, we report the synthesis of a novel 3D cage based on a dodecanuclear $\mathrm{Mo}_{12}$ complex adopting an adamantanoid structure built from four trinuclear $\mathrm{Mo}_{3} \mathrm{~S}_{7}$ entities bridged by six $\mu$-I atoms and encapsulating one iodide anion. This discrete cluster was first obtained as an unexpected product, but a detailed study has since revealed the experimental factors leading to its efficient self-assembly.

In recent years, our research interests have focused on the coordination of redox-active ligands such as 1,2-dithiolenes to the trinuclear $\mathrm{Mo}_{3} \mathrm{~S}_{7}$ cluster, ${ }^{6}$ to afford dianionic $\left[\mathrm{Mo}_{3} \mathrm{~S}_{7}(1,2 \text {-dithiolene })_{3}\right]^{2-}$ complexes, which after chemical or electrochemical oxidation afford single-component conductors. ${ }^{7}$ During the course of this work we have explored the coordination chemistry of 1,2-dioxolenes. The compound $\left(\mathrm{PPh}_{4}\right)_{2}\left[\mathrm{Mo}_{3} \mathrm{~S}_{7}\left(\mathrm{Cl}_{4} \mathrm{cat}\right)_{3}\right]\left(\left(\mathrm{PPh}_{4}\right)_{2}[1]\right)\left(\mathrm{Cl}_{4}\right.$ cat $=$ tetrachlorocatecholate) is prepared in high yield by treatment of $\left[\mathrm{Mo}_{3} \mathrm{~S}_{7} \mathrm{Br}_{6}\right]^{2-}$ with an excess of $\mathrm{Cl}_{4} \mathrm{CatH}_{2}$ in the presence of triethylamine. $\dagger$ Unexpectedly, the slow diffusion of an excess of iodine into $\left(\mathrm{PPh}_{4}\right)_{2}[\mathbf{1}]$ solutions produces $\left(\mathrm{PPh}_{4}\right)_{3}\left[\mathrm{Mo}_{3} \mathrm{~S}_{7} \mathrm{I}_{3}\right]_{4}(\mu-\mathrm{I})_{6} \mathrm{I}\left(\left(\mathrm{PPh}_{4}\right)_{3}[2]\right)$. Optimal conditions for its preparation were found using a 3:1 iodine to $\left(\mathrm{PPh}_{4}\right)_{2}[\mathbf{1}]$ ratio, which led to compound $\left(\mathrm{PPh}_{4}\right)_{3}[2]$ in moderate yield $(c a .40 \%)$. $\dagger$ The use of low iodine to $\left(\mathrm{PPh}_{4}\right)_{2}[1]$ ratios (typically below $3: 1)$ reduced the yield of $\left(\left(\mathrm{PPh}_{4}\right)_{3}[2]\right)$, while the use of higher ratios did not improve the yield. On the basis of the ratios of $\mathrm{Mo}_{3} \mathrm{~S}_{7}: \mathrm{I}_{2}$ used for optimal preparation of $\left(\mathrm{PPh}_{4}\right)_{3}$ [2], the proposed stoichiometry is shown in eqn (1).

$$
\begin{aligned}
& 4\left(\mathrm{PPh}_{4}\right)_{2}\left[\mathrm{Mo}_{3} \mathrm{~S}_{7}\left(\mathrm{Cl}_{4} \mathrm{cat}\right)_{3}\right]+12 \mathrm{I}_{2} \\
& \quad \rightarrow\left(\mathrm{PPh}_{4}\right)_{3}\left\{\left[\mathrm{Mo}_{3} \mathrm{~S}_{7} \mathrm{I}_{3}\right]_{4}(\mu-\mathrm{I})_{6} \mathrm{I}\right\}+5 \mathrm{PPh}_{4} \mathrm{I}+3 \mathrm{Cl}_{4} \text { cat }
\end{aligned}
$$

The molecular structure of $\left(\mathrm{PPh}_{4}\right)_{3}[2]$ has been determined by X-ray diffraction methods. $\ddagger$ The compound crystallizes in the acentric cubic space group $P \overline{4} 3 n$ and is comprised of dodecanuclear trianion units built from four $\mathrm{Mo}_{3} \mathrm{~S}_{7}$ trinuclear clusters (Fig. 1). The repeating metal core can be written as $\mathrm{Mo}_{3} \mathrm{~S}_{7} \mathrm{I}_{3} \mathrm{I}_{3 / 2}$, where three bridging iodides connect the trinuclear $\mathrm{Mo}_{3} \mathrm{~S}_{7}$ units. Each trinuclear unit consists of an equilateral $\mathrm{Mo}_{3}$ triangle capped by a $\mu_{3}-\mathrm{S}^{2-}$ atom that lies above the $\mathrm{Mo}_{3}$

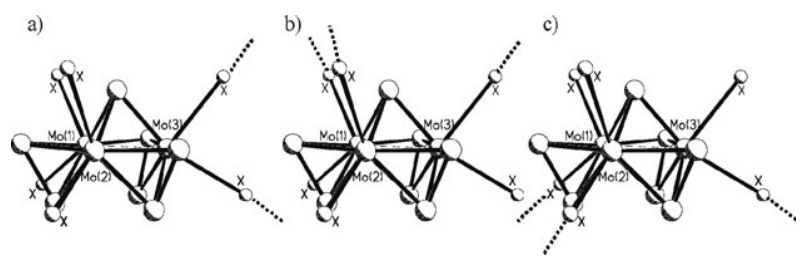

Scheme 1 


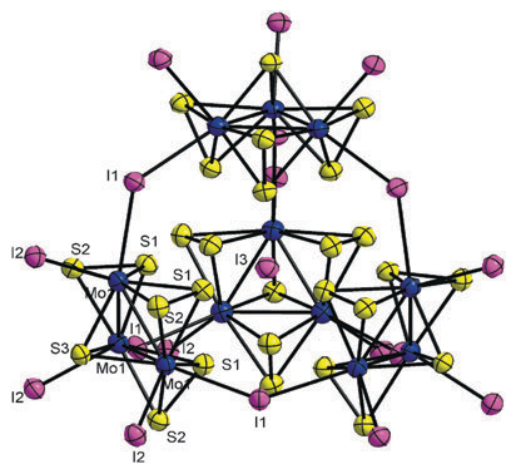

Fig. 1 ORTEP representations of anion $2^{3-}$; Mo-Mo 2.738(2), Mo-I 2.783(2), Mo-I $\mathrm{I}_{\text {bridge }}$ 2.914(1), $\mathrm{S}_{\mathrm{ax}} \cdots \mathrm{I}_{\text {interstitial }}$ 3.293(4) $\mathrm{A}$.

plane. Additionally, the three Mo-Mo edges are bridged by three $\mu-\mathrm{S}_{2}{ }^{2-}$ groups, with sulfur atoms occupying equatorial positions $\left(\mathrm{S}_{\mathrm{eq}}\right.$, those labeled $\left.\mathrm{S}(2)\right)$, essentially in the $\mathrm{Mo}_{3}$ plane, and axial positions $\left(\mathrm{S}_{\mathrm{ax}}\right.$, labeled $\mathrm{S}(1)$ ) located out of the metal plane. Two iodide ligands fill the remaining two positions of the seven-coordinate molybdenum atoms and are oriented almost perpendicular to the $\mathrm{Mo}_{3}$ plane. The bridging iodides define the octahedral assembly of a discrete molecular cage that closely resembles an adamantine-like structure. This octahedron circumscribes two different cuboctahedrons defined by the $12 \mathrm{~S}_{\mathrm{ax}}$ or $\mathrm{S}_{\mathrm{eq}}$ atoms (see Fig. $\mathrm{S} 2 \dagger$ ) and also the tetrahedron defined by the centroids of the four $\mathrm{Mo}_{3}$ units. $^{8}$

The formation of the discrete dodecanuclear cluster $\left(\mathrm{PPh}_{4}\right)_{3}[2]$ is unprecedented despite the rich structural chemistry of $\mathrm{Mo}_{3} \mathrm{Q}_{7}$ complexes $(\mathrm{Q}=\mathrm{S}, \mathrm{Se}) . \mathrm{Mo}_{3} \mathrm{Q}_{7}(\mathrm{Q}=\mathrm{S}, \mathrm{Se})$ based supramolecular aggregates are ubiquitous in the solid state owing to the prominent electrophilic character of the three axial sulfur atoms. In the present work, the presence of an interstitial iodide-anion close to the "electrophilic" axial sulfur atoms $d\left(\mathrm{~S}_{\mathrm{ax}} \cdots \mathrm{I}_{\text {interstitial }}\right)=3.293(4) \AA$ clearly illustrate this behaviour. From this, the $\mathrm{Mo}_{3} \mathrm{Q}_{7}$ cores derive the ability to form non-covalent links to other anions, giving di-, tri-, tetra- or polymeric clusters of discrete $\mathrm{Mo}_{3} \mathrm{Q}_{7}$ modules.

With the aim of acquiring further insight into the experimental factors leading to the self-assembly of compound $\left(\mathrm{PPh}_{4}\right)_{3}[2]$, we sought additional ways to synthesize $\left(\mathrm{PPh}_{4}\right)_{3}[2]$ by starting from $\left(\mathrm{PPh}_{4}\right)_{2}[1]$ and using different experimental conditions. The reaction of other non-oxidizing iodine sources, namely $\mathrm{PPh}_{4} \mathrm{I}$ or $\left(n-\mathrm{Bu}_{4} \mathrm{~N}\right) \mathrm{I}$ with cluster $\left(\mathrm{PPh}_{4}\right)_{2}[\mathbf{1}]$ in different solvents did not lead to $\mathrm{Cl}_{4}$ cat replacement, highlighting the fact that $\mathrm{Cl}_{4}$ cat to iodide replacement is triggered by ligand oxidation. Catecholate displacement in the complex $\left[\mathrm{Mn}\left(\mathrm{Br}_{4} \mathrm{cat}\right)_{3}\right]^{3-}\left(\mathrm{Br}_{4} \mathrm{cat}=\right.$ tetrabromocatecholate $)$ also requires the presence of an external oxidant such as air to afford the $\left.\left[\mathrm{Mn}\left(\mathrm{Br}_{4} \mathrm{cat}\right)_{2} \text { (solvent }\right)_{2}\right]^{-}$anion. ${ }^{9}$ It has to be pointed out that metal-directed self-assembly typically involves simple procedures and gives high yields, which is ascribed to the thermodynamic stability of the 3D cage compound. However, in the present work, direct mixing of dichloromethane solutions of the cluster $\left(\mathrm{PPh}_{4}\right)_{2}[\mathbf{1}]$ and iodine at room temperature or under reflux conditions did not lead to the formation of the cage $\left(\mathrm{PPh}_{4}\right)_{3}$ [2] complex; the trinuclear $\left(\mathrm{PPh}_{4}\right)_{2}\left[\mathrm{Mo}_{3} \mathrm{~S}_{7} \mathrm{I}_{6}\right] \quad\left(\left(\mathrm{PPh}_{4}\right)_{2}[3]\right)$ compound being obtained

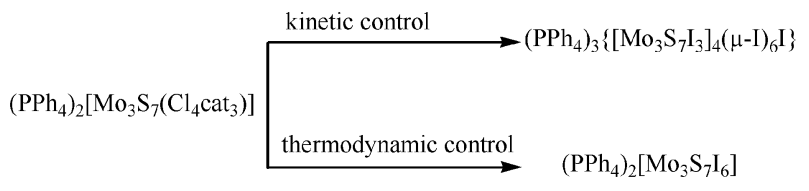

Scheme 2

instead in an almost quantitative yield. $\dagger$ This distinctive reactivity represents a unique example where two different products, $\left(\mathrm{PPh}_{4}\right)_{3}[2]$ and $\left(\mathrm{PPh}_{4}\right)_{2}[3]$, can be isolated under a set of experimental conditions that differs in the rate of $\mathrm{Cl}_{4}$ cat oxidation. We thus suggest that slow iodine oxidation of $\left(\mathrm{PPh}_{4}\right)_{2}[1]$ yields, after a relatively short reaction time, the adamantane-like cage $\left(\mathrm{PPh}_{4}\right)_{3}[2]$, which can be trapped from the reaction mixture as the $\mathrm{PPh}_{4}{ }^{+}$salt. Conversely, the trinuclear $\left(\mathrm{PPh}_{4}\right)_{2}[3]$ is obtained after prolonged heating and therefore represents the thermodynamically favoured product (see Scheme 2).

We have also investigated the effect of the counter-cation as the structural template for the formation of the $\left(\mathrm{PPh}_{4}\right)_{3}[2]$ complex. Oxidation of other salts of the $\mathbf{1}^{2-}$ cluster, such as the $n$ - $\mathrm{Bu}_{4} \mathrm{~N}^{+}, \mathrm{Et}_{4} \mathrm{~N}^{+}$or PPN ${ }^{+}$(PPN $=$bis(triphenyl-phosphine)iminium) salts did not lead to the characteristic crystalization of the $2^{3-}$ cage complex. Only substitution of $\mathrm{PPh}_{4}{ }^{+}$by the topologically related $\mathrm{AsPh}_{4}{ }^{+}$cation afforded, upon reaction with iodine, the isostructural $\left(\mathrm{AsPh}_{4}\right)_{3}[2]$ cage species, as confirmed by their solid state UV-vis spectra and XPD patterns. $\dagger$ This result is a good indication that the solubility of the cage is affected by the presence of $\mathrm{PPh}_{4}{ }^{+}$or $\mathrm{AsPh}_{4}{ }^{+}$ cations, which do "intercept" (and precipitate) the 3D cage complex. Finally, it is also reasonable to hypothesize that the $\mathrm{S}_{\mathrm{ax}} \cdots \mathrm{I}_{\text {interstitial }}$ interaction observed in the solid state structure of $\mathbf{2}^{3-}$ might play a significant role at pre-organizing the tetrahedral configuration of the $\mathrm{Mo}_{3} \mathrm{~S}_{7}$ clusters around the iodide-templating atom. To evaluate this possibility we have carried out the reaction of the starting $\left(\mathrm{PPh}_{4}\right)_{2}[\mathbf{1}]$ with $\mathrm{I}_{2}$ in the presence of $\mathrm{PPh}_{4} \mathrm{X}(\mathrm{X}=\mathrm{Cl}, \mathrm{Br})$ salts and we observed that the characteristic appearance of single-crystals of $\left(\mathrm{PPh}_{4}\right)_{3}[2]$ was dramatically reduced. This suggests that the non-covalent $\mathrm{S}_{\mathrm{ax}} \cdots \mathrm{I}_{\text {interstitial }}$ interaction plays an important role in promoting the self-assembly of the $3 \mathrm{D}\left(\mathrm{PPh}_{4}\right)_{3}[2]$ cage. A closely related example that emphasizes the importance of this $\mathrm{S}_{\mathrm{ax}} \cdots \mathrm{I}_{\text {interstitial }}$ interaction has been recently reported, namely $\left\{\left[\mathrm{Mo}_{3} \mathrm{~S}_{7}(\mathrm{dtp})_{3}\right]_{4} \cdot \mathrm{I}\left(\mathrm{HgI}_{3}\right)_{3}\right\}$ in which four $\mathrm{Mo}_{3} \mathrm{~S}_{7}$ clusters with dithiophosphate ligands are arranged around an interstitial iodide atom. ${ }^{10}$

The thermal stability of compounds $\left(\mathrm{PPh}_{4}\right)_{3}[2]$ and $\left(\mathrm{PPh}_{4}\right)_{2}$ [3] upon heating are very similar, with basically flat TG-DTA curves up to $c a .300{ }^{\circ} \mathrm{C}$ and hence a remarkable thermal stability. At higher temperatures, between 300 and $600{ }^{\circ} \mathrm{C}$, exothermic processes occur with mass losses of ca. $65 \%$ (for $\left.\left(\mathrm{PPh}_{4}\right)_{3}[2]\right)$ and $60 \%\left(\right.$ for $\left.\left(\mathrm{PPh}_{4}\right)_{2}[3]\right)$. Furthermore, XPD experiments at different temperatures for compound $\left(\mathrm{PPh}_{4}\right)_{3}$ [2] showed a gradual loss of crystallinity starting from $250{ }^{\circ} \mathrm{C}$ to yield an amorphous solid above $300{ }^{\circ} \mathrm{C}$. Both TG-DTA and XPD measurements rule out a plausible interconversion from $\left(\mathrm{PPh}_{4}\right)_{3}[2]$ to $\left(\mathrm{PPh}_{4}\right)_{2}[3]$ in the solid state.

Compound $\left(\mathrm{PPh}_{4}\right)_{3}[2]$ is not soluble in common organic solvents (toluene, $\mathrm{CHCl}_{3}$, tetrahydrofuran, $\mathrm{CH}_{3} \mathrm{CN}, \mathrm{CH}_{3} \mathrm{OH}$ ). 
a)

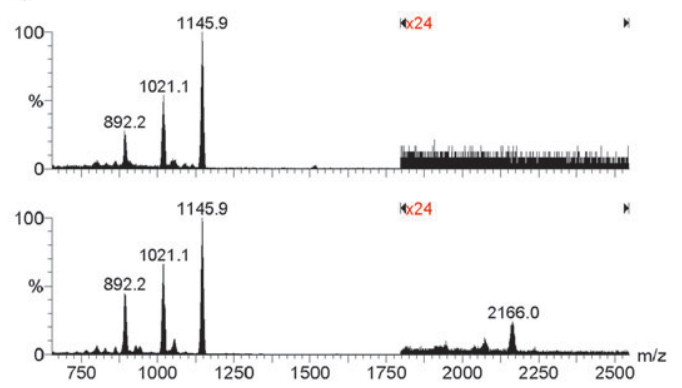

b)

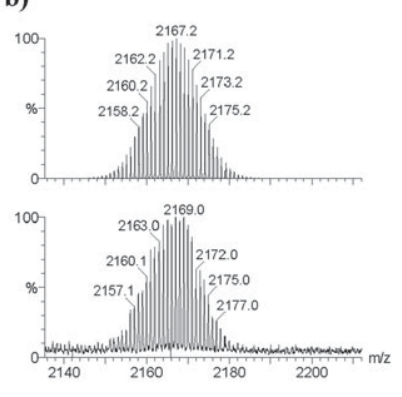

Fig. 2 (a) ESI mass spectra of dimethylformamide- $\mathrm{CH}_{3} \mathrm{CN}$ solutions of compound $\left(\mathrm{PPh}_{4}\right)_{3}$ [2] (bottom) after immediate dissolution (bottom) and after $c a$. $10 \mathrm{~min}$ (top). Note that the $m / z=1800-2500$ range has been increased 24-fold to highlight the species present; (b) Simulated (top) and experimental (bottom) isotopic pattern of the $\left[\mathrm{Mo}_{6} \mathrm{~S}_{14} \mathrm{I}_{9}\right]^{-}$species.

It slowly dissolves in dimethylformamide under stirring to give an orange solution whose UV-Vis spectrum is identical to that of complex $\left(\mathrm{PPh}_{4}\right)_{2}[3]$, thus suggesting that the molecular $2^{3-}$ cage is dismantled in solution to yield $\mathbf{3}^{2-}$. However, electrospray ionization (ESI) provides strong evidence for the presence of larger aggregates prior to complete $2^{3-}$ to $\mathbf{3}^{2-}$ transformation occurring in solution. ESI mass spectra of freshly dissolved $\left(\mathrm{PPh}_{4}\right)_{3}$ [2] in dimethylformamide recorded at different time intervals are shown in Fig. 2.

Initially, the presence of the hexanuclear $\left[\mathrm{Mo}_{6} \mathrm{~S}_{14} \mathrm{I}_{9}\right]^{-}$ $(m / z=2167.2)$ species is observed (Fig. 2a, bottom). This decays over time (Fig. 2a, top) to finally disappear after $c a .20 \mathrm{~min}$. It is reasonable to hypothesize that aggregate $\left[\mathrm{Mo}_{6} \mathrm{~S}_{14} \mathrm{I}_{9}\right]^{-}$is an intermediate species resulting from the disruption of the cage $2^{3-}$. ESI mass spectra also show additional trinuclear $\left[\mathrm{Mo}_{3} \mathrm{~S}_{7} \mathrm{I}_{5}\right]^{-}(m / z=1145.9),\left[\mathrm{Mo}_{3} \mathrm{~S}_{7} \mathrm{I}_{4}\right]^{-}(m / z=1021.1)$ and $\left[\mathrm{Mo}_{3} \mathrm{~S}_{7} \mathrm{I}_{3}\right]^{-}(m / z=892.2)$ anions, as well as $\left[\mathrm{Mo}_{3} \mathrm{~S}_{7} \mathrm{I}_{6}\right]^{2-}$ $(m / z=637.5)$ dianions, which are also observed upon ESI of $\left(\mathrm{PPh}_{4}\right)_{2}[3]$ under identical conditions.

In summary, we report the first example of polyhedral molecules assembled from trinuclear corner pieces and iodide linkers which were obtained via spontaneous self-assembly. It is clear that in the self-assembly of complex architectures, a number of kinetic products may appear before formation of the thermodynamic product(s). In the present system, both the kinetic and thermodynamic products have been successfully isolated and characterized, mainly because of their distinctive solubility. It is shown that iodine oxidation of the dioxolene $\left[\mathrm{Mo}_{3} \mathrm{~S}_{7}\left(\mathrm{Cl}_{4} \mathrm{cat}\right)_{3}\right]^{2-}$ complex forms the thermodynamically stable $\left[\mathrm{Mo}_{3} \mathrm{~S}_{7} \mathrm{I}_{6}\right]^{2-}\left(3^{2-}\right)$ dianion by way of a metastable adamantine-like cage trianion, namely $\mathbf{2}^{3-}$, which can be intercepted fleetingly as a $\mathrm{PPh}_{4}{ }^{+}$and $\mathrm{AsPh}_{4}{ }^{+}$salt. Besides the importance of the counter-cation, our results also reveal that the presence of iodide either as bridging-ligands or interstitials play a crucial role in the self-assembly of the 3D $\left(\mathrm{PPh}_{4}\right)_{3}[2]$ cage.

This work was made possible through the support of the Spanish Ministerio de Ciencia e Innovación (Projects CTQ2008-02670/BQU and MAT2008-04350/NAN)

\section{Notes and references}

$\ddagger$ Crystal data. For $\left(\mathrm{PPh}_{4}\right)_{2}[1]: \mathrm{C}_{67} \mathrm{H}_{42} \mathrm{Cl}_{14} \mathrm{Mo}_{3} \mathrm{O}_{6} \mathrm{P}_{2} \mathrm{~S}_{7}, M=2013.49$, monoclinic, space group $P 2_{1} / c, a=20.565(4) \AA, b=25.840(5) \AA$, $c=14.510(3) \AA, \beta=99.27(3), V=7610(3)(3) \AA^{3}, Z=4, T=293(2) \mathrm{K}$,
42587 reflections measured, 13370 unique $\left(R_{\text {int }}=0.1044\right)$. Final $R=0.0633(I>2 \sigma(I))$ and $\mathrm{w} R=0.1857$ (all data). For $\left(\mathrm{PPh}_{4}\right)_{3}[2] \cdot 2 \mathrm{Me}_{2} \mathrm{C}=\mathrm{O}: \mathrm{C}_{78} \mathrm{H}_{72} \mathrm{I}_{19} \mathrm{Mo}_{12} \mathrm{O}_{2} \mathrm{P}_{3} \mathrm{~S}_{28}, M=5594.33$, cubic, space group $P \overline{4} 3 n, a=19.086(4) \AA, V=6953(3) \AA^{3}, Z=2$, $T=100(2) \mathrm{K}, 51071$ reflections measured, 2278 unique $\left(R_{\mathrm{int}}=0.0808\right)$. Final $R 1=0.0532(I>2 \sigma(I))$ and $\mathrm{w} R=0.1275$ (all data). For $\left(\mathrm{PPh}_{4}\right)_{2}$ [3]: $\mathrm{C}_{48.50} \mathrm{H}_{41} \mathrm{ClI}_{6} \mathrm{Mo}_{3} \mathrm{P}_{2} \mathrm{~S}_{7}, M=1994.84$, monoclinic, space group $P 2_{1} / c, a=18.519(1) \AA, b=20.911(1) \AA, c=17.2686(9) \AA$, $\beta=106.822(1)^{\circ} . V=6401.0(6) \AA^{3}, Z=4, T=293(2) \mathrm{K}, 42209$ reflections measured, 14670 unique $\left(R_{\mathrm{int}}=0.0454\right)$. Final $R=0.0391$ $(I>2 \sigma(I))$ and $\mathrm{w} R=0.1291$ (all data). CCDC 713962 for $\left(\mathrm{PPh}_{4}\right)_{2}[\mathbf{1}]$, 713964 for $\left(\mathrm{PPh}_{4}\right)_{3}[2]$ and 713963 for $\left(\mathrm{PPh}_{4}\right)_{2}[3]$. $\dagger$

1 (a) S. Leininger, B. Olenyuk and P. Stang, Chem. Rev., 2000, 100, 853; (b) M. Fujita, Chem. Soc. Rev., 1998, 27, 417; (c) M. Fujita, M. Tominaga, A. Hori and B. Therrien, Acc. Chem. Res., 2005, 38, 371; (d) P. N. W. Baxter, J.-M. Lehn and A. Decian, Angew. Chem., Int. Ed. Engl., 1993, 32, 69; (e) P. N. W. Baxter, J.-M. Lehn, B. O. Kneisel, G. Baum and D. Fenske, Chem.-Eur. J., 1999, 5, 113; $(f)$ B. J. Holliday and C. A. Mirkin, Angew. Chem., Int. Ed., 2001, 40, 2022.

2 (a) F. A. Cotton, C. Lin and C. A. Murillo, Acc. Chem. Res., 2001, 34, 759; (b) M. H. Chisholm and A. N. Macintosh, Chem. Rev., 2005, 105, 2949.

3 V. P. Fedin, Y. V. Mironov, A. V. Virovets, N. V. Podberezskaya and V. Y. Fedorov, Polyhedron, 1992, 11, 2083.

4 (a) L. R. MacGillivray and J. L. Atwood, Angew. Chem., Int. Ed., 1999, 38, 1018; (b) M. Yamanaka, Y. Yamada, Y. Sei, K. Yamaguchi and K. Kobayashi, J. Am. Chem. Soc., 2006, 128, 1531; (c) D. L. Caulder and K. N. Raymond, Acc. Chem. Res., 1999, 32, 975; (d) R. J. Prins, D. N. Reinhoudt and P. Timmerman, Angew. Chem., Int. Ed., 2001, 40, 2382; (e) F. Hof, S. L. Craig, C. Nuckolls and J. J. Rebek, Angew. Chem., Int. Ed., 2002, 41, 1488; (f) S. R. Seidel and P. J. Stang, Acc. Chem. Res., 2002, 35, 972-983; (g) J. J. Rebek, Angew. Chem., Int. Ed., 2005, 44, 2068.

5 (a) A. A. Opalowskii, V. E. Fedorov and K. A. Khaldoyanidi, Akad. Nauk. SSSR, 1968, 182, 1095; (b) J. Marcoll, A. Rabenau, D. Mootz and H. Wunderlich, Rev. Chim. Miner., 1974, 11, 607.

6 (a) J. M. Garriga, R. Llusar, S. Uriel, C. Vicent, A. J. Usher, N. T. Lucas, M. G. Humphrey and M. Samoc, Dalton Trans., 2003, 4546; (b) A. Alberola, R. Llusar, S. Triguero, C. Vicent, M. M. Sokolov and C. Gómez-Garcia, J. Mater. Chem., 2007, 17, 3440 .

7 (a) R. Llusar, S. Uriel, C. Vicent, E. Coronado, C. J. GomezGarcia, J. M. Clemente-Juan, B. Braida and E. Canadell, J. Am. Chem. Soc., 2004, 126, 12076; (b) R. Llusar, S. Triguero, V. Polo, C. Vicent, C. J. Gomez-Garcia, O. Jeannin and M. Fourmigue, Inorg. Chem., 2008, 47, 9400.

8 J. Echeverria, D. Casanova, M. Llunell, P. Alemany and S. Alvarez, Chem. Commun., 2008, 2717.

9 C. J. Rolle, III, K. I. Hardcastle and J. D. Soper, Inorg. Chem., 2008, 47, 1892.

10 J. Chen, S. F. Lu, Z. X. Huang, R. M. Yu and Q. J. Wu, Chem.-Eur. J., 2001, 7, 2002. 